\title{
Local community perception on the contribution of port companies to sustainable development
}

\section{Percepção da comunidade local sobre a contribuição das empresas portuárias para o desenvolvimento sustentável}

\author{
Luciane Silva Franco Mestre em Desenvolvimento Comunitário. Universidade Estadual do Centro-Oeste \\ https://orcid.org/0000-0003-1913-9275 (UNICENTR0) - Brasil. Lu05-franco@hotmail.com \\ Sergio Luis Dias Doliveira Doutor em Administração. Universidade Estadual do Centro-Oeste (UNICENTRO) - Brasil. \\ https://orcid.org/0000-0001-9957-225X sldd@uol.com.br. \\ Antonio Carlos Franco Doutorando em Administração. Pontifícia Universidade Católica do Paraná (PUC-PR) - \\ https://orcid.org/0000-0003-1616-2648 Brasil. francoancf@hotmail.com \\ Simone Soares Mestre em Desenvolvimento Comunitário. Universidade Estadual do Centro-0este \\ https://orcid.org/0000-0002-0282-2599 (UNICENTRO) - Brasil. simosoares@gmail.com
}

\begin{abstract}
The purpose of the study presented in this article was to analyze the local community perception on the sustainable development of port companies in a specific region. The research carried out a data collection, following quantitative methods. The study sample was collected through a survey questionnaire applied to the residents in the area around the Brazilian town of Paranaguá in the state of Paraná, Brazil. The article reveals the factors of environmental, social and economic impact of the companies as well as emphasizes the problematic aspects of relationships between the activities of the port companies and local communities. The correlation between the variables in the questionnaire applied by the Ethos Institute (2007) was tested. The perception of residents regarding the environmental, social and economic impacts of the companies was measured according to the profile considering gender, age, education level and years the residents live in the town. The significant difference was tested using Kruskal Wallis and Mann-Whitney while correlation was tested using Spearman Correlation. The result showed that the negative perception is statistically different in terms of gender, age and years the residents live in the town. Concerning correlation, categories of economic and social impacts are significantly and positively related.
\end{abstract}

Keywords: sustainability; indicators; port administration; community.

\section{RESUMO}

O objetivo do estudo apresentado neste artigo foi analisar a percepção da comunidade local sobre o desenvolvimento sustentável das empresas portuárias em uma determinada região. A pesquisa realizou coleta de dados, seguindo métodos quantitativos. A amostra do estudo foi coletada por meio de questionário de pesquisa com residentes localizados no entorno da cidade brasileira de Paranaguá, no estado do Paraná, Brasil. $\mathrm{O}$ artigo revela os fatores de impacto ambiental, social e econômico das empresas, bem como enfatiza os aspectos problemáticos das relações entre as atividades das empresas portuárias e as comunidades locais. Foi testada a correlação entre as variáveis do questionário aplicado pelo Instituto Ethos (2007). A percepção dos moradores sobre os impactos ambientais, sociais e econômicos das empresas foi mensurada de acordo com o perfil considerando sexo, idade, escolaridade e anos de residência na cidade. A diferença significativa foi testada usando Kruskal Wallis e Mann-Whitney, enquanto a correlação foi testada usando Correlação de Spearman. O resultado mostrou que a percepção negativa é estatisticamente diferente em relação ao sexo, idade e anos de residência na cidade. Em correlação, as categorias de impactos econômicos e sociais estão significativa e positivamente relacionados.

Palavras-chave: sustentabilidade; indicadores; administração portuária; comunidade. 


\section{INTRODUCTION}

In the process of globalization of the world market, maritime trade is extremely important. The port system is part of the world maritime market, where exchanges between land and sea transport operators take place. Countries with developed maritime transport focus special attention on the sustainable development of ports (Cheon, Maltz, \& Dooley, 2017). The fundamental issue involves the integration of land and sea transport, storage and freight transport (Vejvar, Lai, Lo, \& Fürst, 2018).

The development in technology, quantity and quality of maritime transport, in recent years, has been developing very quickly. It is stated that the main challenge regarding the growth of maritime transport is the transport of goods from one place to another in an economically viable and as efficient way as possible (Bjerkan \& Seter, 2019). The transport systems of the ports have become complex due to the variety of cargo they operate and their location close to the regions of local communities. For this reason, the correct management related to safety, occupational health, environment and protection factors by the ports is fundamental (Vejvar et al., 2018; Kim \& Chiang, 2017).

Therefore, the environmental responsibilities of companies that perform port activities present great challenges, such as, for example, the demand for changes in logistics processes and reduction of pollution emissions (air, water and soil) from current and future port activities (Beleya, Veerappan, Ding, \& Tan, 2020; Lozano, Fobbe, Carpenter, \& Sammalisto, 2019). Environmental responsibilities are essentially related to vessel and cargo handling operations, port planning and extension and access to the interior. In addition, society and public institutions present charges from companies in this sector for demands on the performance of social responsibility (Hossain, Adams, \& Walker, 2019).

As a result of awareness about efficient sustainable activities, strict environmental laws and obtaining a competitive advantage, port companies need to carry out their operations in a sustainable and transparent manner. In this way, the companies' systems need communication platforms with the community and other stakeholders about their operating activities, selecting clear criteria for obtaining the data (Bjerkan \& Seter, 2019).

Due to the representativeness of sustainable performance, logistics activities, which operate in accordance with the principle of sustainable development, are turning their attention to the green and sustainable management of the activities of port companies. Green and sustainable management presents different approaches to decision making and strategies based on competences and knowledge because there is an environmental risk involved in the activities and sustainable development of the port system (Hossain et al., 2019; Linder, 2018).

As several stakeholders are involved in the activities of a port, the responsibility of everyone is fundamental, as well as the integration of communication, in order to ensure sustainable performance in the port service. With the adoption of the ISO 14001 standard, sustainable performance can be achieved by all stakeholders (Di Vaio, Varriale, \& Alvino, 2018; Vejvar et al., 2018).

There is a tendency in Europe for companies that provide port services to cooperate with sustainability, through interconnections in communication with the local community (Jansen, van Tulder, \& Afrianto, 2018). In Italy, a survey was conducted on the factors that hinder or encourage port companies to plan sustainable solutions (Di Vaio et al., 2018).

However, despite the interest of port systems in sustainable development, it is surprising that so little research has been carried out on this topic. Mainly with regard to the harmony of the environmental and economic responsibilities of port activities with the local community. Research by the local community in port settings is sparse: little research has focused on how port authorities and company managers use power to interact with the local community (Chen \& Lam, 2018; Linder, 2018).

Therefore, in view of the considerations presented, the purpose of the study in this article was to analyze the local community perception on the sustainable development of port companies in a specific region. We focused on the specific municipality of Paranaguá with 154,936 inhabitants and 44 port companies. The port sector represents $27 \%$ of all registered job creation activities in the municipality. In addition, activities linked to the port inject some $\mathrm{R} \$ 1.2$ billion into Brazil's annual economy, with $25 \%$ responsible for paying workers' wages (IBGE, 2019). 
Despite the positive aspects of this sector for the municipality, as a contribution at an economic and social level, due to the movement of loads and the generation of jobs, the municipality faces some challenges that end up generating negative aspects for residents (AEN, 2020).

According to AEN (2020), the bulk most exported through the port of Paranaguá is soy, and the moving by road of this product is very intense. This type of movement ends up affecting problems in the daily lives of residents, such as paving infrastructure, traffic congestion, bad smell and impacts on the health of the residents. In addition, it causes an environmental, social, and economic threat to the local community.

This study contributes to the literature by exploring in depth, through field research with residents of the region, the environmental, social and economic impacts of port companies on the local community. In addition, the research analyzes the significant difference in the perception of the impact on the sustainability of the local community, concerning profile of residents by gender, age, education level and years live in the town.

The study also presents practical contributions by bringing forward discussions that generate learning for managers of family businesses, in particular, by revealing the sustainable development of port companies and their impacts on the local community. Thus, it is possible to identify and select the organizational behavior that should be practiced to benefit the quality of life of the local community.

\section{THEORETICAL FRAMEWORK}

Sustainable development (SD) as a social and political process in society has provided a direction to find alternatives for sustainable practices in society (Newton \& Henley, 2002). There is a growing interest in research on sustainability or sustainable development and with approaches that involve ecology, corporate social responsibility, conscious consumption, strategic planning, clean production, environmental management, among other topics. The approach varies according to the research area (administration, economics, engineering, biology, geography, among others), where each science studies with its different form of analysis, but with common goals regarding sustainability (Lawer, Herbeck, \& Flitner, 2019).

The concepts of sustainable development and sustainability can be misinterpreted, and sometimes even synonymous. However, in scientific research these concepts are not seen in this way. For Kang and Kim (2017), sustainability involves solutions for the depletion of nature's resources, seeking its continuous use. In a broad view, according to Hossain et al., (2019), sustainability is not seen as an environmental movement, but with a way of thinking and behaving in society that has become increasingly mature in recent years. Sustainable development, according to Linder (2018), is related to establishing strategies to aggregate resources that provide environmental, social and economic growth.

Elkington (1994) was the one who developed the term "Triple Bottom Line", focused on the perspective of companies, where sustainable development is related to environmental, economic and social development. The Triple Bottom Line seeks a harmony of concepts in a balanced way, which may cause changes in local development (Manteaw, 2008). Local development is understood as a process of improving the economic, social and environmental aspects of a given area based on the use of endogenous resources to improve the well-being and quality of life of its population (Marzi \& Logozar, 2019).

\subsection{Environmental impact}

One of the main challenges of sustainable development is that companies start to contribute to the protection of the environment, through environmental management models and the rational use of economic resources within the legislation. Therefore, companies need to act within ethics, which involves the organizational image within the environmentally correct concepts (Hui, Aye, \& Duffield, 2019).

Environmental management aims to collaborate in the improvement of practices and policies in the operational and administrative sector, which gives way to companies' commitment to the environment. In addition, it provides planning and strategies achieving goals. Therefore, it reduces the environmental threats generated as a result of its actions, seeking to achieve environmental responsibility (Md Sapry, Umar, Ahmad, \& Baskaran, 2020; Severo, Guimarães, Dellarmelin, \& Ribeiro, 2019). 
The environmental management system involves planning, organizing, directing and controlling activities to improve, analyze and critically consider environmental policies (Franco, Doliveira, \& Franco, 2020). These actions reduce damage to the environment and contribute to the achievement of the desired environmental goals of the company. To identify the conditions to carry out environmental policies and to adopt conducts for the fulfillment of the determined goals, the dissemination of analysis and prevention activities, and verification is essential (Pugliano, Benassai, \& Benassai, 2019).

\subsection{Social impact}

Social Responsibility (RS) is one of the processes to achieve sustainability. The adoption of the principles of social responsibility, such as commitment and transparency, can help guarantee the viability and long-term success of any organization or system (Schrobback \& Meath, 2020).

The Social Responsibility Theory is formed by an ethics system, in which decisions and behaviors need to be ethically validated before proceeding. If the action or decision creates threats to society or the environment, it would be considered socially irresponsible. The moral values inherent in society create a distinction between right and wrong. Every individual has a responsibility to act in a way that is beneficial to society and not just for the individual (Muafi, 2017).

\subsection{Economic impact}

The concepts of economic development and economic growth are different. Economic growth is related to the continuous growth of GDP (gross domestic product) at per capita and global level (LópezBermúdez, Freire-Seoane, \& Nieves-Martínez, 2019). The increase in the production of goods and services can be caused by improvements in the quality of education, technologies or other ways in which there is added value in goods and services produced by sectors of the economy (Laerhoven \& Barnes, 2014).

Economic development is the increase in productivity associated with organizational and technical changes, that is, structural changes in the production and allocation of resources. Thus, "growth" is a consequence of "development" (López-Bermúdez et al., 2019).

According to Vejvar et al. (2018) as companies acquire resources from society, they have an obligation to compensate not only in the form of economic growth with trade in products and services, but, through social behaviors related to solving problems that affect society. Therefore, in economic responsibility, it is through society that the company presents its viability, using human and technological resources as part of an economic and social heritage.

\subsection{Sustainable development of port companies and the impact on the local community}

The port sector can contribute in several dimensions to sustainability in community development. The growth of the port sector and the community is complementary and, therefore, it must take active actions for the development of the port, companies, community and other local stakeholders (Marzi \& Logozar, 2019; Jansen et al., 2018).

Among the consequences caused by the failure of communication between port, company and community, there is the main challenge faced by port companies in terms of social scope, the quality of life of the community that residents the region's surroundings (Jansen et al., 2018).

There is a difficulty in distinguishing the limits of the port areas, including the port and companies in the surroundings, as they are intrinsically linked to the commercial and residential areas of the municipality. There is an infrastructure gap that impacts the local community, as it is increasingly necessary to increase capacity to accommodate larger volumes of cargo. Therefore, the expansion of companies in urban and suburban areas is essential, due to the intense congestion (Newton \& Henley, 2002).

For this reason, the potential impacts influence the quality of life of the population, among which involve dust due to the movement of solid bulk, odor from the fuel of transport vehicles and waste from spilling cargo on the highways, noise emission when carrying out the operations,intense vehicle traffic, especially in the harvest period for the case of food bulk (Franco et al., 2020; Kang \& Kim, 2017). 


\section{METHODOLOGY}

This section presents the methodology adopted in this research. Operational framework, data collection and research instrument are presented.

\subsection{Operational framework}

This paper, through the use of set of samples, will increase and further support the current literature and eventually influence port companies to adopt sustainable practices that reduce the environmental, social and economic impacts of the local community. Based in the operational framework (see Figure 1), the following hypotheses will be tested:

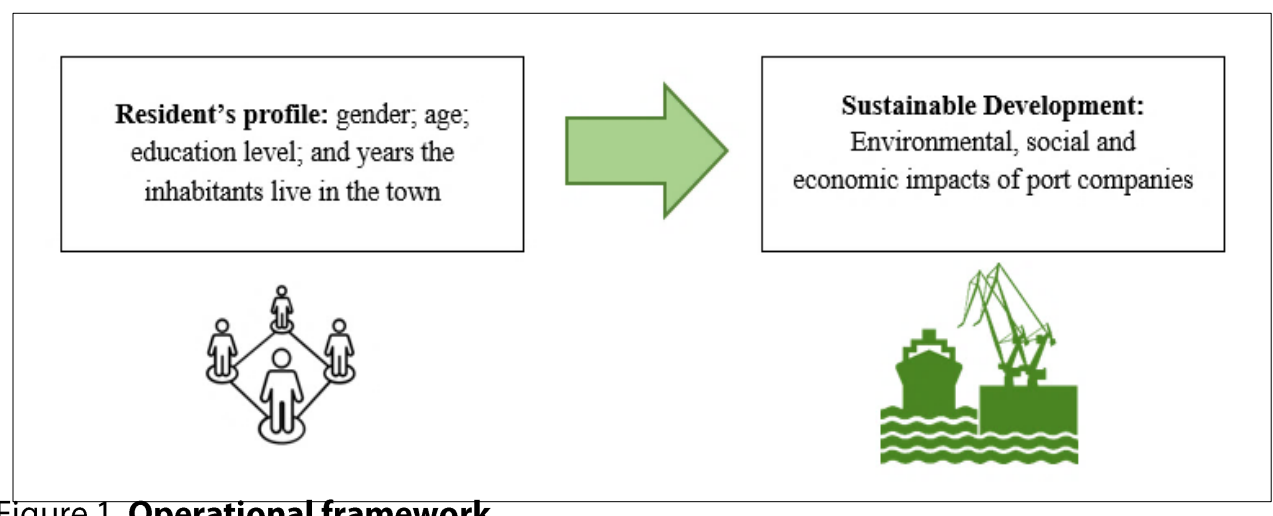

Figure 1. Operational framework

Source: own authorship (2021).

H01- The distribution of environmental impact is the same across categories of gender.

$\mathrm{H} 02$ - The distribution of social impact is the same across categories of gender.

$\mathrm{H} 03$ - The distribution of economic impact is the same across categories of gender.

$\mathrm{H} 04$ - The distribution of environmental impact is the same across categories of age.

$\mathrm{H} 05$ - The distribution of social impact is the same across categories of age.

$\mathrm{H} 06$ - The distribution of economic impact is the same across categories of age.

$\mathrm{H} 07$ - The distribution of environmental impact is the same across categories of education level.

$\mathrm{H} 08$ - The distribution of social impact is the same across categories of education level.

$\mathrm{H} 09$ - The distribution of economic impact is the same across categories of education level.

$\mathrm{H} 10$ - The distribution of environmental impact is the same across categories of years live in the town.

$\mathrm{H} 11$ - The distribution of social impact is the same across categories of years live in the town.

$\mathrm{H} 12$ - The distribution of economic impact is the same across categories of years lived in the town.

\subsection{Data collection and research instrument}

To test the hypotheses proposed an empirical study was done based on an electronic questionnaire given to residents in the town of Paranaguá. The selection of the respondents was done with a convenience sample, using emails and WhatsApp, obtaining a total of 339 valid questionnaires after eliminated those which contained inconsistent answers or which did not fulfill the criteria suggested by Taherdoost (2016). The collection of information via the online questionnaire was carried out during the months August and September 2020. The description of the sample is detailed in the section Results and Discussion.

Regarding the measurement instruments used, all the constructs were measured based on 5 point Likert scales (1-never; 2- rarely; 3-sometimes; 4- often; and 5-always; where value five indicates the negative impact high (in the environmental, social and economic impact); value one indicates the positive impact high (in the economic, environmental, and social impact). All the scales are made up of indicators extracted from the theoretical review and specifically adapted of this study, centered on the resident's perception. A total of 
nine impact dimensions (divided into environmental, social, and economic) were extracted from the proposal elaborated by Ethos Institute (2017), as show in Table 1:

\begin{tabular}{|c|c|}
\hline No. & A. Environmental \\
\hline QA1 & $\begin{array}{l}\text { The emission of dust from the operations of companies can have an impact on the region's } \\
\text { environment. }\end{array}$ \\
\hline QA2 & Vehicle traffic occurs intensely, causing traffic congestion in the region. \\
\hline QA3 & $\begin{array}{l}\text { The noise emission in the performance operations of companies occurs intensely in the } \\
\text { region. }\end{array}$ \\
\hline No. & B. Social \\
\hline QB1 & $\begin{array}{l}\text { The services provided by the companies may represent potential risks to the health and well- } \\
\text { being of the surrounding community. }\end{array}$ \\
\hline QB2 & $\begin{array}{l}\text { The companies have actions in the surrounding community to minimize the risks to human } \\
\text { rights in their operations, such as notifying when operations that emit intense noise are } \\
\text { carried out. }\end{array}$ \\
\hline eseQB3 & $\begin{array}{l}\text { Companies contribute to improvements in infrastructure or the local environment and these } \\
\text { are enjoyed by the community (such as housing and roads). }\end{array}$ \\
\hline No. & C. Economic \\
\hline QC1 & $\begin{array}{l}\text { Companies invest financial resources for social projects in communities, such as health, } \\
\text { education and leisure. }\end{array}$ \\
\hline QC2 & The community benefits from social projects that are carried out by companies. \\
\hline QC3 & $\begin{array}{l}\text { The ground transportation services of companies cause economic impacts in the } \\
\text { municipality, such as asphalt deterioration. }\end{array}$ \\
\hline
\end{tabular}

Table 1. Disclosure checklist

Source: adapted from Instituto Ethos (2017).

Before testing the significant difference among the perception about the impact of sustainable development of port companies, and profile of residents, the researcher has tested the normality of distribution of the data using Kolmogorov-Smirnov normality test. As a result, all variables showed a nonnormal distribution, p.value $<0,05$ (Table 2).

\begin{tabular}{llll}
\hline Kolmogorov-Smirnov $^{1}$ & & & \\
\hline Variables & Statistic & P.value & Remarks \\
\hline QA1 & 0,352 & $<0,001$ & Not normal \\
QA2 & 0,354 & $<0,001$ & Not normal \\
QA3 & 0,289 & $<0,001$ & Not normal \\
QB1 & 0,266 & $<0,001$ & Not normal \\
QB2 & 0,326 & $<0,001$ & Not normal \\
QB3 & 0,306 & $<0,001$ & Not normal \\
QC1 & 0,302 & $<0,001$ & Not normal \\
QC2 & 0,344 & $<0,001$ & Not normal \\
QC3 & 0,300 & $<0,001$ & Not normal \\
\hline
\end{tabular}

${ }^{1}$ Lilliefors Significance Correction

Table 2. Test of Normality

Source: own authorship (2021).

The Kruskal-Wallis test was used to compare three or more independent samples and the MannWhitney test for two independent samples. These are non-parametric tests used in the presence of $k$ independent samples, to determine whether the samples are from the same population or whether at least one sample is from a different population than the others. The $p$. value of the tests was inserted in the table caption with the respective descriptive statistics. 
In order to compare the categories two by two to determine which differ, with a statistical significance of $5 \%$, concerning distribution of the mean, the pairwise comparison procedure was used to estimate the onedimensional fundamental scale in which the elements of each level are measured. The Spearman test was used to evaluate correlation, justified by the non-normal distribution. The following interpretation was used (Table 3):

\begin{tabular}{ll}
\hline Correlation Coefficient $\mathrm{p}$ value $(+$ or -$)$ & Strength of Correlation \\
\hline $0,00-0,19$ & Very Strong \\
$0,20-0,39$ & Strong \\
$0,40-0,69$ & Moderate \\
$0,70-0,89$ & Weak \\
$0,90-1,00$ & Very weak \\
\hline
\end{tabular}

Table 3. Correlation Coefficient

Source: Devore (2006)

In addition, the correlation coefficient and the p. value $(<0.05)$ are always observed. The sign indicates positive or negative direction of the relationship.

\section{RESULTS AND DISCUSSION}

Table 4 presents as frequencies of profile variables, considering gender, age, education level and lives in the town (per year).

\begin{tabular}{lll}
\hline Gender & Frequency & Percent \\
\hline Female & 205 & 52,7 \\
Male & 184 & 47,3 \\
\hline Age & Frequency & Percent \\
\hline Less than 20 years & 16 & 4,1 \\
$20-29$ years & 68 & 17,5 \\
$30-39$ years & 105 & 27,0 \\
$40-49$ years & 109 & 28,0 \\
$50-59$ years & 70 & 18,0 \\
$60-69$ years & 16 & 4,1 \\
Over 69 years & 5 & 1,3 \\
\hline Education level & Frequency & Percent \\
\hline None & 6 & 1,5 \\
Primary & 15 & 3,9 \\
High School & 177 & 45,5 \\
College/University & 144 & 37,0 \\
Graduate School & 47 & 12,1 \\
\hline Lives in the town (per year) & Frequency & Percent \\
\hline Less than 1 year & 12 & 3,1 \\
1 year & 17 & 4,4 \\
2 years & 33 & 8,5 \\
3 years & 43 & 11,1 \\
Up to 5 years & 79 & 20,3 \\
Up to 10 years & 56 & 14,4 \\
More than 10 years & 149 & 38,3 \\
\hline
\end{tabular}

Table 4. Frequencies of profile variables

Source: own authorship (2021). 
Most respondents are women (52,7\%), at the age of 40-49 (28\%), high school education level $(45,5 \%)$ and lives in the town more than 10 years (38,3\%). Table 5 presents the gender relationship by environmental, social and economic impacts.

\begin{tabular}{|c|c|c|c|c|c|c|c|}
\hline \multicolumn{8}{|c|}{ Environmental (p. value 0,048 ) } \\
\hline & Mean & $\mathrm{N}$ & $\begin{array}{l}\text { Std. } \\
\text { Deviation }\end{array}$ & Median & Variance & Minimum & Maximum \\
\hline Female & 4,21 & 205 & 0,55 & 4,33 & 0,31 & 2,33 & 5,00 \\
\hline Male & 3,54 & 184 & 0,66 & 3,00 & 0,44 & 1,00 & 5,00 \\
\hline \multicolumn{8}{|c|}{ Social (p. value 0,787 ) } \\
\hline & Mean & $\mathrm{N}$ & $\begin{array}{l}\text { Std. } \\
\text { Deviation }\end{array}$ & Median & Variance & Minimum & Maximum \\
\hline Female & 2,03 & 205 & 0,80 & 2,00 & 0,65 & 1,00 & 5,00 \\
\hline Male & 2,09 & 184 & 0,87 & 2,00 & 0,76 & 1,00 & 5,00 \\
\hline \multicolumn{8}{|c|}{ Economic (p. value 0,035 ) } \\
\hline & Mean & $\mathrm{N}$ & $\begin{array}{l}\text { Std. } \\
\text { Deviation }\end{array}$ & Median & Variance & Minimum & Maximum \\
\hline Female & 3,01 & 205 & 0,98 & 3,00 & 0,97 & 1,00 & 5,00 \\
\hline Male & 2,09 & 184 & 1,00 & 2,00 & 1,00 & 1,00 & 5,00 \\
\hline
\end{tabular}

Table 5. Gender relationship by environmental, social and economic impacts

Source: own authorship (2021).

In the environmental impact, there is a significant difference by gender with p.value $<0,05$, rejecting the null hypothesis $\mathrm{H} 01$ (the distribution of environmental impact is the same across categories of gender). Thus, it is concluded that women have a greater negative perception of the environmental impact, when compared to men.

In the social impact there is no significant difference by gender with p.value $>0.05$, accepting the null hypothesis $\mathrm{HO2}$ (the distribution of social impact is the same across categories of gender). In the economic impact, there is a significant difference by gender with p.value $<0.05$, rejecting the null hypothesis $\mathrm{H} 03$ (the distribution of economic impact is the same across categories of gender). Thus, it is concluded that women have a greater negative perception of the economic impact, when compared to men. Table 6 presents the age relationship by environmental, social and economic impacts.

\begin{tabular}{|c|c|c|c|c|c|c|c|}
\hline \multicolumn{8}{|c|}{ Environmental (p. value 0,331 ) } \\
\hline & Mean & $\mathrm{N}$ & Std. Deviation & Median & Variance & Minimum & Maximum \\
\hline Less than 20 years & 4,10 & 16 & 0,58 & 4,00 & 0,33 & 3,00 & 5,00 \\
\hline $20-29$ years & 4,34 & 68 & 0,35 & 4,33 & 0,12 & 2,33 & 5,00 \\
\hline $30-39$ years & 4,20 & 105 & 0,57 & 4,33 & 0,33 & 2,33 & 5,00 \\
\hline $40-49$ years & 4,16 & 109 & 0,59 & 4,33 & 0,35 & 2,00 & 5,00 \\
\hline $50-59$ years & 4,19 & 70 & 0,68 & 4,33 & 0,47 & 1,00 & 5,00 \\
\hline $60-69$ years & 4,18 & 16 & 0,54 & 4,33 & 0,29 & 3,00 & 5,00 \\
\hline Over 69 years & 4,21 & 5 & 1,21 & 4,33 & 1,47 & 1,00 & 5,00 \\
\hline \multicolumn{8}{|c|}{ Social (p. value 0,157 ) } \\
\hline & Mean & $\mathrm{N}$ & Std. Deviation & Median & Variance & Minimum & $\begin{array}{l}\text { Maximu } \\
\mathrm{m}\end{array}$ \\
\hline Less than 20 years & 2,06 & 16 & 0,92 & 2,00 & 0,86 & 1,00 & 5,00 \\
\hline $20-29$ years & 1,83 & 68 & 0,61 & 2,00 & 0,37 & 1,00 & 3,00 \\
\hline $30-39$ years & 2,03 & 105 & 0,85 & 2,00 & 0,72 & 1,00 & 5,00 \\
\hline $40-49$ years & 2,13 & 109 & 0,93 & 2,00 & 0,87 & 1,00 & 5,00 \\
\hline $50-59$ years & 2,14 & 70 & 0,78 & 2,00 & 0,61 & 1,00 & 4,00 \\
\hline
\end{tabular}




\begin{tabular}{|c|c|c|c|c|c|c|c|}
\hline $60-69$ years & 2,37 & 16 & 0,95 & 2,00 & 0,91 & 1,00 & 4,00 \\
\hline Over 69 years & 2,20 & 5 & 0,83 & 2,00 & 0,70 & 1,00 & 3,00 \\
\hline \multicolumn{8}{|c|}{ Economic (p. value 0,000$)$} \\
\hline & Mean & $\mathrm{N}$ & Std. Deviation & Median & Variance & Minimum & $\begin{array}{l}\text { Maximu } \\
\mathrm{m}\end{array}$ \\
\hline Less than 20 years & 2,31 & 16 & 0,94 & 2,00 & 0,89 & 1,00 & 5,00 \\
\hline $20-29$ years & 1,60 & 68 & 0,75 & 1,50 & 0,57 & 1,00 & 5,00 \\
\hline $30-39$ years & 2,06 & 105 & 1,06 & 2,00 & 1,14 & 1,00 & 5,00 \\
\hline $40-49$ years & 2,19 & 109 & 1,01 & 2,00 & 1,02 & 1,00 & 5,00 \\
\hline $50-59$ years & 2,08 & 70 & 0,91 & 2,00 & 0,83 & 1,00 & 4,00 \\
\hline $60-69$ years & 2,62 & 16 & 1,20 & 2,50 & 1,45 & 1,00 & 5,00 \\
\hline Over 69 years & 2,00 & 5 & 0,00 & 2,00 & 0,00 & 2,00 & 2,00 \\
\hline
\end{tabular}

\section{Table 6. Age relationship by environmental, social and economic impacts}

Source: own authorship (2021).

In the environmental and social impact, no significant differences were observed by age with p.value> 0.05 , accepting the null hypotheses $\mathrm{H} 04$ and $\mathrm{H} 05$. In the economic impact, there is a significant difference by age with $\mathrm{p}$. value $<0.05$, rejecting $\mathrm{H} 06$ that the distribution of economic impact is the same across categories of age. The results presented in Figure 2 refer to the pairwise comparison procedure, used to compare pairs of age categories concerning economic impact.

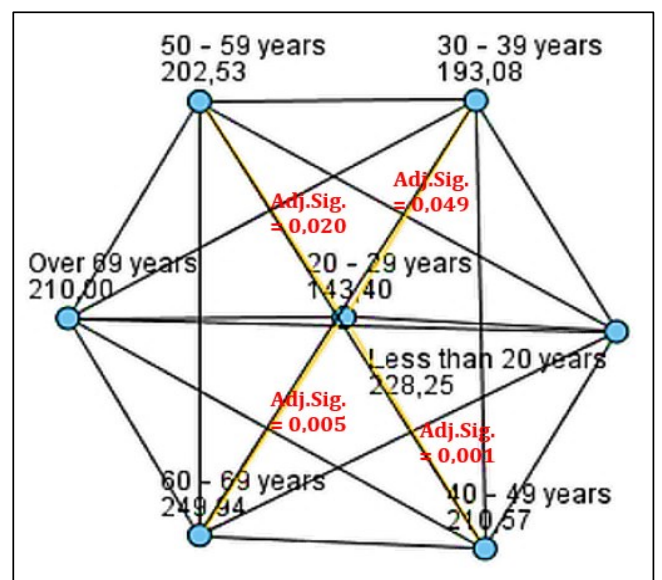

Figure 2. Pairwise comparison (age and economic impact)

Source: own authorship (2021).

Thus, observing the averages (Table 6) and p. value of comparisons in pairs (Figure 2) it can be concluded that residents aged 20-29 years old have a lower negative perception of economic impacts compared to the perception of residents aged 30-39, 40-49, 50-59 and 60-69 years old. Table 7 presents the education level relationship by environmental, social and economic impacts.

\begin{tabular}{lcclllll}
\hline \multicolumn{7}{c}{ Environmental (p. value 0,657) } & \\
\hline Education level & Mean & $\mathrm{N}$ & $\begin{array}{l}\text { Std. } \\
\text { Deviation }\end{array}$ & Median & Variance & Minimum & Maximum \\
None & 4,44 & 6 & 0,27 & 4,50 & 0,07 & 4,00 & 4,67 \\
Primary & 4,15 & 15 & 0,56 & 4,33 & 0,31 & 3,00 & 5,00 \\
High School & 4,21 & 177 & 0,56 & 4,33 & 0,31 & 2,00 & 5,00 \\
\hline
\end{tabular}




\begin{tabular}{|c|c|c|c|c|c|c|c|}
\hline College/University & 4,20 & 144 & 0,62 & 4,33 & 0,38 & 1,00 & 5,00 \\
\hline Graduate School & 4,05 & 47 & 0,79 & 4,33 & 0,62 & 1,00 & 5,00 \\
\hline \multicolumn{8}{|c|}{ Social (p. value 0,437 ) } \\
\hline Education level & Mean & $\mathrm{N}$ & $\begin{array}{l}\text { Std. } \\
\text { Deviation }\end{array}$ & Median & Variance & Minimum & Maximum \\
\hline None & 1,83 & 6 & 0,75 & 2,00 & 0,56 & 1,00 & 3,00 \\
\hline Primary & 1,93 & 15 & 1,09 & 2,00 & 1,21 & 1,00 & 5,00 \\
\hline High School & 2,01 & 177 & 0,74 & 2,00 & 0,55 & 1,00 & 5,00 \\
\hline College/University & 2,16 & 144 & 0,88 & 2,00 & 0,78 & 1,00 & 5,00 \\
\hline Graduate School & 2,04 & 47 & 0,95 & 2,00 & 0,91 & 1,00 & 5,00 \\
\hline \multicolumn{8}{|c|}{ Economic (p. value 0,710$)$} \\
\hline Education level & Mean & $\mathrm{N}$ & $\begin{array}{l}\text { Std. } \\
\text { Deviation }\end{array}$ & Median & Variance & Minimum & Maximum \\
\hline None & 1,66 & 6 & 0,51 & 2,00 & 0,26 & 1,00 & 2,00 \\
\hline Primary & 2,20 & 15 & 1,01 & 2,00 & 1,02 & 1,00 & 5,00 \\
\hline High School & 2,03 & 177 & 1,03 & 2,00 & 1,07 & 1,00 & 5,00 \\
\hline College/University & 2,04 & 144 & 0,93 & 2,00 & 0,87 & 1,00 & 5,00 \\
\hline Graduate School & 2,17 & 47 & 1,04 & 2,00 & 1,10 & 1,00 & 5,00 \\
\hline
\end{tabular}

Table 7. Education level relationship by environmental, social and economic impacts

Source: own authorship (2021).

In the environmental, social and economic impact, no significant differences were observed by level of education with p.value $>0.05$, accepting the null hypotheses of $\mathrm{H07}, \mathrm{H} 08$ and $\mathrm{H} 09$. However, it is interesting to highlight that the environmental impact presents the average of negative perception within scale 4, while the average of the negative perception of social and economic impacts appears within scales 1 and 2. However, the environmental impact can be presented as a factor determinant that negatively impacts the sustainable development of the town. Table 8 presents the years the residents live in the town relationship by environmental, social and economic impacts.

\begin{tabular}{|c|c|c|c|c|c|c|c|}
\hline \multicolumn{8}{|c|}{ Environmental (p. value 0,189 ) } \\
\hline $\begin{array}{l}\text { Lives in the } \\
\text { town (per year) }\end{array}$ & Mean & $\mathrm{N}$ & $\begin{array}{l}\text { Std. } \\
\text { Deviation }\end{array}$ & Median & Variance & Minimum & Maximum \\
\hline Less than 1 year & 4,19 & 12 & 0,59 & 4,33 & 0,35 & 3,00 & 5,00 \\
\hline 1 year & 4,29 & 17 & 0,35 & 4,33 & 0,12 & 3,33 & 4,67 \\
\hline 2 years & 4,06 & 33 & 0,65 & 4,33 & 0,42 & 2,33 & 5,00 \\
\hline 3 years & 4,08 & 43 & 0,63 & 4,33 & 0,40 & 2,33 & 5,00 \\
\hline Up to 5 years & 4,30 & 79 & 0,56 & 4,33 & 0,32 & 2,33 & 5,00 \\
\hline Up to 10 years & 4,25 & 56 & 0,42 & 4,33 & 0,18 & 3,00 & 5,00 \\
\hline $\begin{array}{l}\text { More than } 10 \\
\text { years }\end{array}$ & 4,15 & 149 & 0,69 & 4,33 & 0,48 & 1,00 & 5,00 \\
\hline \multicolumn{8}{|c|}{ Social (p. value 0,001 ) } \\
\hline $\begin{array}{l}\text { Lives in the town } \\
\text { (per year) }\end{array}$ & Mean & $\mathrm{N}$ & $\begin{array}{l}\text { Std. } \\
\text { Deviation }\end{array}$ & Median & Variance & Minimum & Maximum \\
\hline Less than 1 year & 2,08 & 12 & 1,16 & 2,00 & 1,35 & 1,00 & 5,00 \\
\hline 1 year & 1,64 & 17 & 0,49 & 2,00 & 0,24 & 1,00 & 2,00 \\
\hline 2 years & 1,82 & 33 & 0,81 & 3,00 & 0,67 & 1,00 & 4,00 \\
\hline 3 years & 2,16 & 43 & 0,78 & 2,00 & 0,61 & 1,00 & 5,00 \\
\hline Up to 5 years & 2,13 & 79 & 0,99 & 2,00 & 0,99 & 1,00 & 5,00 \\
\hline Up to 10 years & 3,07 & 56 & 0,83 & 2,00 & 0,69 & 1,00 & 5,00 \\
\hline
\end{tabular}




\begin{tabular}{|c|c|c|c|c|c|c|c|}
\hline $\begin{array}{l}\text { More than } 10 \\
\text { years }\end{array}$ & 3,10 & 149 & 1,02 & 3,00 & 1,05 & 1,00 & 4,00 \\
\hline \multicolumn{8}{|c|}{ Economic (p. value 0,000 ) } \\
\hline $\begin{array}{l}\text { Lives in the town } \\
\text { (per year) }\end{array}$ & Mean & $\mathrm{N}$ & $\begin{array}{l}\text { Std. } \\
\text { Deviation }\end{array}$ & Median & Variance & Minimum & Maximum \\
\hline Less than 1 year & 2,08 & 12 & 1,08 & 2,00 & 1,17 & 1,00 & 5,00 \\
\hline 1 year & 2,00 & 17 & 0,79 & 2,00 & 0,62 & 1,00 & 4,00 \\
\hline 2 years & 2,06 & 33 & 1,11 & 2,00 & 1,24 & 1,00 & 5,00 \\
\hline 3 years & 2,09 & 43 & 0,97 & 2,00 & 0,94 & 1,00 & 4,00 \\
\hline Up to 5 years & 1,98 & 79 & 1,04 & 2,00 & 1,09 & 1,00 & 5,00 \\
\hline Up to 10 years & 2,05 & 56 & 0,98 & 2,00 & 0,96 & 1,00 & 5,00 \\
\hline $\begin{array}{l}\text { More than } 10 \\
\text { years }\end{array}$ & 2,61 & 149 & 1,16 & 2,00 & 1,36 & 1,00 & 5,00 \\
\hline
\end{tabular}

Table 8. Lives in the town (per year) relationship by environmental, social and economic impacts Source: own authorship (2021).

In the environmental impact, no significant differences were observed by years the residents live in the town, with p.value $>0.05$, accepting the null hypotheses $\mathrm{H} 10$. In the social and economic impact, there is a significant difference by years the residents live in the town with $\mathrm{p}$. value $<0.05$, rejecting $\mathrm{H} 11$ e $\mathrm{H} 12$ that the distribution of social and economic impact is the same across categories. The results presented in Figure 3 refer to the pairwise comparison procedure, used to compare pairs of categories of years the residents live in the town concerning social impact.

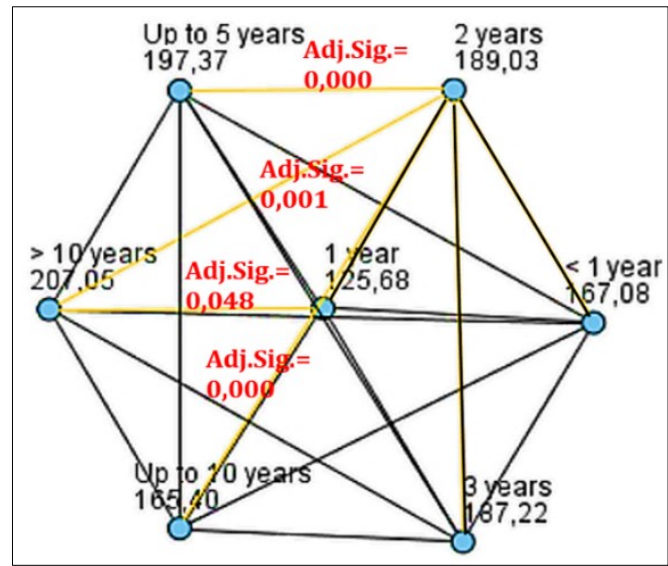

Figure 3. Pairwise comparison (years the residents live in the town and social impact)

Source: own authorship (2021)

Thus, observing the averages (Table 8) and p. value of comparisons in pairs (Figure 3) it can be concluded that residents who have lived for more than 10 years have a greater negative perception of social impact when compared to the perception of residents who live for 2 years and up to 5 years. Thus, it is concluded that the longer the dwelling time in the town, the greater the negative perception about the social impact caused by the companies.

The same results can be seen in the research by Jansen et al., (2018), which highlights that, over the years, the social impacts in port cities can increase frequently. The main challenge faced by port companies is related to the social sphere, concerning quality of life of the community that residents the region's surroundings. According to Beleya et al., (2020), these challenges that involve potential impacts, must interact with the sustainable goals of port companies in what corresponds not only to the environmental and economic impact, but also to the social impact.

Currently, there is a constant concern in evaluating the company as a social organization and not just an economic one. Society values companies with behaviors aimed at social demands, in addition to preserving 
the quality of life of the community in the city to which it is inserted (Bjerkan \& Seter, 2019). The results presented in Figure 4 refer to the pairwise comparison procedure, used to compare pairs of categories of years the residents live in the town concerning economic impact.

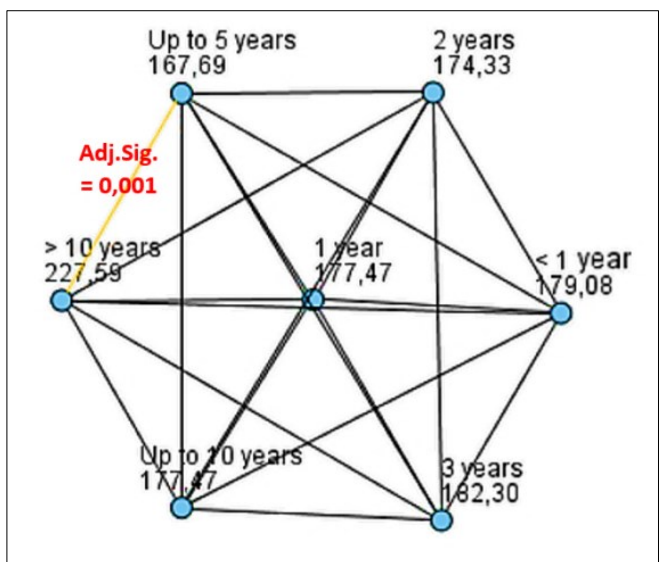

Figure 4. Pairwise comparison (years the residents live in the town and economic impact)

Source: own authorship (2021)

Thus, observing the averages (Table 8) and p. value of comparisons in pairs (Figure 4) it can be concluded that residents who have lived for more than 10 years have a greater negative perception of economic impact when compared to the perception of residents living up to 5 years. Thus, it is concluded that the longer the dwelling time in the town, the greater the negative perception about the economic impact caused by the companies.

Regarding the economic impact, the indicators to be considered should include job creation, local economic development, and investment of financial resources in social projects. When acquiring resources from society, companies have an obligation to compensate not only in the form of economic growth with trade in products and services, but, through social behaviors related to solving problems that affect society (Vejvar, et al, 2018). In addition, negative actions due to the services of port companies must be avoided, such as the deterioration of asphalt by land transport and the spillage of cargo on the highways. However, the negative perception of residents about the economic impact (Md Sapry et al., 2020).

Table 9 presents the estimates of Spearman's linear correlation coefficients between environmental, social and economic impacts.

\begin{tabular}{|c|c|c|c|c|c|c|c|c|c|c|}
\hline & & $\bar{d}$ & 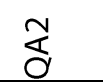 & $\stackrel{m}{\Delta}$ & $\overline{\tilde{o}}$ & $\stackrel{\text { ฒै }}{0}$ & $\stackrel{m}{\ddot{\theta}}$ & $\bar{y}$ & ঠ্ব & $\stackrel{m}{0}$ \\
\hline \multirow[t]{2}{*}{ QA1 } & Correlation Coefficient & 1,000 & & & & & & & & \\
\hline & Sig. (2-tailed) & . & & & & & & & & \\
\hline \multirow[t]{2}{*}{ QA2 } & Correlation Coefficient & 0,071 & 1,000 & & & & & & & \\
\hline & Sig. (2-tailed) & 0,160 & . & & & & & & & \\
\hline \multirow[t]{2}{*}{ QA3 } & Correlation Coefficient & 0,257 & 0,324 & 1,000 & & & & & & \\
\hline & Sig. (2-tailed) & 0,000 & 0,000 & . & & & & & & \\
\hline \multirow[t]{3}{*}{ QB1 } & Correlation Coefficient & 0,189 & - & - & 1,000 & & & & & \\
\hline & & & 0,257 & 0,152 & & & & & & \\
\hline & Sig. (2-tailed) & 0,000 & 0,000 & 0,003 & . & & & & & \\
\hline \multirow[t]{3}{*}{ QB2 } & Correlation Coefficient & - & - & 0,252 & 0,700 & 1,000 & & & & \\
\hline & & 0,086 & 0,275 & & & & & & & \\
\hline & Sig. (2-tailed) & 0,091 & 0,000 & 0,000 & 0,000 & & & & & \\
\hline
\end{tabular}




\begin{tabular}{|c|c|c|c|c|c|c|c|c|c|c|}
\hline \multirow[t]{3}{*}{ QB3 } & Correlation Coefficient & 0,152 & 0,202 & 0,235 & - & - & 1,000 & & & \\
\hline & & & & & 0,026 & 0,099 & & & & \\
\hline & Sig. (2-tailed) & 0,003 & 0,000 & 0,000 & 0,607 & 0,052 & . & & & \\
\hline \multirow[t]{3}{*}{ QC1 } & Correlation Coefficient & - & 0,127 & 0,097 & - & 0,035 & 0,097 & 1,000 & & \\
\hline & & 0,056 & & & 0,113 & & & & & \\
\hline & Sig. (2-tailed) & 0,273 & 0,012 & 0,057 & 0,026 & 0,487 & 0,057 & . & & \\
\hline \multirow[t]{3}{*}{ QC2 } & Correlation Coefficient & 0,022 & - & - & 0,536 & 0,518 & - & 0,099 & 1,000 & \\
\hline & & & 0,282 & 0,249 & & & 0,121 & & & \\
\hline & Sig. (2-tailed) & 0,669 & 0,000 & 0,000 & 0,000 & 0,000 & 0,017 & 0,051 & . & \\
\hline \multirow[t]{3}{*}{ QC3 } & Correlation Coefficient & - & - & - & 0,496 & 0,507 & - & 0,065 & 0,584 & 1,000 \\
\hline & & 0,085 & 0,297 & 0,363 & & & 0,175 & & & \\
\hline & Sig. (2-tailed) & 0,093 & 0,000 & 0,000 & 0,000 & 0,000 & 0,001 & 0,200 & 0,000 & . \\
\hline
\end{tabular}

(a) Correlation is significant at the 0.05 level (2-tailed); Correlation is significant at the 0.01 level (2-tailed); Strength of Correlation: $\square$ Moderate $\square$ Weak.

Table 9. Estimates of Spearman's linear correlation coefficients(a) between environmental impacts (QA1, QA2, QA3), social impacts (QB1, QB2, QB3) and economic impacts (QC1, QC2, QC3)

Source: own authorship (2021).

There is a strong and positive correlation between QB1 and QB2; indicating that by increasing the negative perception about potential risks to the health and well-being of the community caused by the provision of services by the companies (QB1), it also increases the negative perception about actions to minimize the risks to the human rights of the community caused by the operations of the companies (QB2). According to the residents' perception, it is noticed that few actions are carried out by port companies in the concern with health, well-being and human rights of the community. López-Bermúdez et al., (2019) describe that among the practices of the Environmental Management System of companies, health and safety protection for both workers and the community must be included.

There is a moderate and positive correlation between $\mathrm{QC2}$ with $\mathrm{QB} 1$ and QB2; indicating that increasing the negative perception about social projects of companies in the community (QC2), also increases the negative perception about risks to the health and well-being of the community (QB1) and actions of companies to minimize risks to human rights (QB2). According to Vejvar et al. (2018), concerning economic aspect of port companies, the indicators to be considered should include job creation, local economic development, and investment of financial resources in social projects.

There is a moderate and positive correlation between QC3 and QB1, QB2 and QC2; indicating that by increasing the negative perception of land transport services by companies that cause economic impacts in the municipality (QC3), it also increases the negative perception of: risks to the health and well-being of the community (QB1); corporate actions to minimize risks to human rights (QB2); and social projects of companies in the community (QC2). The study by Jardas, Schiozzi and Smojver (2020), portrays that internal policies in port companies are necessary to avoid economic impacts in inhabited regions. Among these practices, there is the installation of sound barriers at the edges of the housing areas and the frequent cleaning of asphalt due to the spillage of loads.

\section{CONCLUSION}

This study presented the results of a bibliographic review and data collection on the perception of the local community of a specific region regarding environmental, social and economic impacts of port companies' activities. The hypotheses were tested based on the resident's profile in terms of gender, age, education level and years the residents live in the town. In addition, the tests determined whether there is a significant correlation among the variables. The result showed that the negative perception is statistically 
different in terms of gender, age and years the residents live in the town. In correlation, categories of economic and social impacts are significantly and positively related.

Gender of residents is one variable of influence in the negative perception of the environmental impact generated by port companies; the gender analysis implies that women have a more critical view of dust emission, vehicle traffic and noise emission in the region due to the operations of companies when compared to men. The older age of residents influences the negative perception of the economic impact generated by port companies, which implies that companies invest little financial resources in projects that benefit the community for older people, such as employment and education programs. The variable of years residents live in the town influences the negative perception of the social and economic impacts generated by port companies. This implies that the more years the residents live in the town, the greater the negative impact concerning quality of life of the community (social impact) and structural damage, such as noise, damage to asphalt, pollution from cargo spillage (economic impact).

This result made the companies and local community in the town aware why some residents are showing a negative perception about the sustainability of port companies. By looking from sustainable development point of view, port companies can correctly integrate environmental, social and economic methods into their operations. All companies can have the least negative impact on the local community. Therefore, the contribution of all those involved in port activities (stakeholders) is necessary to achieve indicators of environmental, social and economic control. The indicators assessed include the environment, human rights, security and protection. Notably, the assessment of sustainability performance must include internal sustainability practices (companies) and external collaboration (community). Among the consequences caused by the communication failure between port, company and community is the main challenge faced in order to deal with the social impact, the quality of life of the community that resides in a specific region.

This study only covered only residents of a single town in Brazil. The survey can be extended by capturing the data for other port cities in Brazil to compare with the data from this survey. More so, it encourages extending the research to residents of other countries with ports to enable the gathering of more samples.

\section{REFERENCES}

AEN. Agência de Notícias do Paraná. (2020). Porto de Paranaguá: Histórico. Available in: http://www.aen.pr.gov.br/modules/noticias/article.php?storyid=101470\&tit=Porto-de-Paranagua-faz84-anos-neste-domingo. Accessed on March 10, 2021.

Beleya, P., Veerappan, G., Ding, W. J., \& Tan, J. (2020). Challenges in attaining sustainable development goals in port Klang: Port management perspective. International Journal of Supply Chain Management, 9(1), 349-355.

Bjerkan, K. Y., \& Seter, H. (2019). Reviewing tools and technologies for sustainable ports: Does research enable decision making in ports? Transportation Research Part D: Transport and Environment, 72, 243-260. https://doi.org/10.1016/j.trd.2019.05.003

Chen, C., \& Lam, J. S. L. (2018). Sustainability and interactivity between cities and ports: a two-stage data envelopment analysis (DEA) approach. Maritime Policy and Management, 45(7), 944-961. https://doi.org/10.1080/03088839.2018.1450528

Cheon, S., Maltz, A., \& Dooley, K. (2017). The link between economic and environmental performance of the top 10 U.S. ports. Maritime Policy and Management, 44(2), 227-247. https://doi.org/10.1080/03088839.2016.1275860

Di Vaio, A., Varriale, L., \& Alvino, F. (2018). Key performance indicators for developing environmentally sustainable and energy efficient ports: Evidence from Italy. Energy Policy, 122, 229-240. https://doi.org/10.1016/j.enpol.2018.07.046

Ethos Institute. (2017). Indicadores Ethos para Negócios Sustentáveis e Responsáveis. São Paulo. https://www.ethos.org.br/conteudo/indicadores/ 
Franco, L. S.; Doliveira, S. L. D.; Franco, A. C. (2020). Desenvolvimento Sustentável e o Transporte Urbano em países da América do Sul: uma revisão sistemática. Revista Metropolitana de Sustentabilidade, 10(3), p.159-181.

Hossain, T., Adams, M., \& Walker, T. R. (2019). Sustainability initiatives in Canadian ports. Marine Policy, 106. https://doi.org/10.1016/j.marpol.2019.103519

Hui, F. K. P., Aye, L., \& Duffield, C. F. (2019). Engaging employees with good sustainability: Key performance indicators for dry ports. Sustainability (Switzerland), 11(10). https://doi.org/10.3390/su11102967

IBGE. Instituito Brasileiro de Geografia de Estatística. (2019). Porto de Paranaguá Catálogo. Available in: https://biblioteca.ibge.gov.br/index.php/biblioteca-catalogo? view=detalhes\&id=449759. Accessed on March 12, 2021.

Jansen, M., van Tulder, R., \& Afrianto, R. (2018). Exploring the conditions for inclusive port development: the case of Indonesia. Maritime Policy and Management, 45(7), 924-943. https://doi.org/10.1080/03088839.2018.1472824

Jardas, M., Schiozzi, D., \& Smojver, Z. (2020). Application of Multi-Criteria Analysis of Determining Sea Port Development Models in the Spatial Concept of a Town, Based on the Example of the Town of Rovinj. Tehnicki Vjesnik-Technical Gazette, 27(1), 297-307. https://doi.org/10.17559/TV-20181116194755

Kang, D., \& Kim, S. (2017). Conceptual model development of sustainability practices: The case of port operations for collaboration and governance. Sustainability (Switzerland), 9(12). https://doi.org/10.3390/su9122333

Kim, S., \& Chiang, B. G. (2017). The role of sustainability practices in international port operations: an analysis of moderation effect. Journal of Korea Trade, 21(2). https://doi.org/10.1108/JKT-03-2017-0025

Laerhoven, F. V., \& Barnes, C. (2014). Communities and commons: the role of community development support in sustaining the commons. Community Development Journal, 49(1), 118-132. https://doi.org/10.1093/cdj/bsu005

Lawer, E. T., Herbeck, J., \& Flitner, M. (2019). Selective adoption: How port authorities in Europe and West Africa engage with the globalizing "green port" idea. Sustainability (Switzerland), 11(18). https://doi.org/10.3390/su11185119

Linder, A. (2018). Explaining shipping company participation in voluntary vessel emission reduction programs. Transportation Research Part D: Transport and Environment, 61, 234-245. https://doi.org/10.1016/j.trd.2017.07.004

López-Bermúdez, B., Freire-Seoane, M. J., \& Nieves-Martínez, D. J. (2019). Port efficiency in Argentina from 2012 to 2017: An ally for sustained economic growth. Utilities Policy, 61. https://doi.org/10.1016/j.jup.2019.100976

Lozano, R., Fobbe, L., Carpenter, A., \& Sammalisto, K. (2019). Analysing sustainability changes in seaports: Experiences from the Gävle Port Authority. Sustainable Development, 27(3), 409-418. https://doi.org/10.1002/sd.1913

Manteaw, B. (2008). From tokenism to social justice: rethinking the bottom line for sustainable community development. Community Development Journal, 43(4), 428-443. https://doi.org/10.1093/cdj/bsm015

Marzi, B., \& Logozar, K. (2019). Cooperation Between a Port and Local Community In Light of Sustainable Development. European Journal of Sustainable Development, 8(4, SI), 337-346. https://doi.org/10.14207/ejsd.2019.v8n4p337

Md Sapry, H. R., Umar, F. H., Ahmad, A. R., \& Baskaran, S. (2020). Investigating implementation of green port initiative at johor port berhad. International Journal of Advanced Trends in Computer Science and Engineering, 9(1.1 Special Issue), 80-84. https://doi.org/10.30534/ijatcse/2020/1591.12020

Muafi. (2017). From company reputation to environmental performance. The context of corporate social responsibility port manager in Indonesia. Journal of Environmental Management and Tourism, 8(7), 1386-1398. https://doi.org/10.14505/jemt.v8.7(23).08 
Newton, S. T., Fast, H., \& Henley, T. (2002). Sustainable development for Canada's Arctic and Subarctic communities: A backcasting approach to Churchill, Manitoba. Arctic, 55(3), 281-290. https://doi.org/10.14430/arctic711

Pugliano, G., Benassai, G., \& Benassai, E. (2019). Integrating urban and port planning policies in a sustainable perspective: the case study of Naples historic harbour area. Planning Perspectives, 34(5), 827-847. https://doi.org/10.1080/02665433.2018.1455068

Schrobback, P., \& Meath, C. (2020). Corporate sustainability governance: Insight from the Australian and New Zealand port industry. Journal of Cleaner Production, 255. https://doi.org/10.1016/j.jclepro.2020.120280

Severo, E. A, Guimarães, J. C. F, Dellarmelin, M. L, \& Ribeiro, RP (2019). The Influence of Social Networks on Environmental Awareness and the Social Responsibility of Generations. Brazilian Business Review, 16(5), 500-518. https://doi.org/10.15728/bbr.2019.16.5.5

Taherdoost, H. (2016). Validity and Reliability of the Research Instrument; How to Test the Validation of a Questionnaire/Survey in a Research. International Journal of Academic Research in Management (IJARM), 5(1), 27-36.

Vejvar, M., Lai, K.-H., Lo, C. K. Y., \& Fürst, E. W. M. (2018). Strategic responses to institutional forces pressuring sustainability practice adoption: Case-based evidence from inland port operations. Transportation Research Part D: Transport and Environment, 61, 274-288. https://doi.org/10.1016/j.trd.2017.08.014 